\title{
Corrosion Resistance of Plasma Nitrided Structural Steels
}

David Kusmic, David Dobrocky

Faculty of Military Technology, University of Defence, Kounicova 156/65, 66210 Brno, Czech Republic. E-mail: david.kusmic@unob.cz,david.dobrocky@unob.cz

The plasma nitriding technology was mostly used in the past primarily to increasing of surface hardness a fatigue limit. Additional feature of nitrided steel surface is possibility of corrosion resistance increasing. This additional feature is leading to the increase of lifetime of steel parts and components. This study is focused on the evaluation of corrosion resistance of plasma nitrided AISI 1045 and AISI 4340 steels. The steel samples were plasma nitrided and some of them were additionally oxidised. The corrosion resistance evaluation was performed in a fog of a neutral sodium chloride solution (NSS) according to the ISO 9227 standard. The created nitride and oxinitride layers were metallographically documented (using the light and laser confocal microscopy) and evaluated by measuring of microhardness profiles (Vickers method) under load of $H_{V_{0,5}}$. The thickness of compound surface layers of plasma nitrided and oxidized compound layers was documented by light microscopy and verified by measuring of concentration profiles by the GDOES.

Keywords: Plasma nitriding, corrosion resistance, structural steel

\section{Acknowledgement}

The paper was prepared with the support of the Project for the Development of the Organization and by the Specific research project 2014 of the Department of Mechanical Engineering, UoD "Promoting Research, Science and Inovation in the Field of Engineering".

\section{References}

[1] NIKOLUSSI, M., LEINWEBER, A., et al. (2007). Examination of phase transformations in the system Fe-N-C by means of nitrocarburising reactions and secondary annealing experiments, the $\alpha+\varepsilon$ two-phase equilibrium. In: Material Research, 98, 11, p. 1086-1092, ISSN 1862-5282.

[2] PYE, D. (2003). Practical nitriding and ferritic nitrocarburizing, USA, ISBN 0-87170-791-8.

[3] HOLEMÁŘ, A., HRUBÝ, V. (1988). Plazmová nitridace v praxi, SNTL, Prague, ISBN 80-03-00001-7.

[4] DONG-CHERNG WEN. (2009). Plasma nitriding of plastic mold steel to increase wear- and corrosion properties. In: Surface\&Coatings Technology, 204, p. 511-519, ISSN 0257-8972.

[5] HIRSCH, T., K., et al. (2004). Residual Stress-Affected Diffusion during Plasma Nitriding of Tool Steel. In: Metallurgical and Materials Transactions A, vol. 35A, November, p. 3523 - 3530, ISSN: 1073-5623.

[6] KUSMIČ, D., SVOBODA, E., HRUBÝ, V. (2007). Surface quality and the nitride layer properties, Surface and Cotatings 2007. Rožnov pod Radhoštěm, p. 73 - 77, ISBN 978-80-969310-4-0.

[7] KUSMIČ, D., HRUBÝ, V. (2008). Corrosion resistance of plasma nitrided structural steels and modern methods of testing. In: Advances in Military Technology, Volume 3, Issue 1, p. 65-75, ISSN 1802-2308.

[8] SUKÁČ, J., POSPÍCHAL, M., et al. (2010). Effect of Subsequent Thermal Treatment on Properties of Plasma Nitrided Low Alloyed Steel GOST 67SiCr5. In: Materials Structure \& Micromechanics of Fracture, Brno, p. 179, ISBN 978-80-214-4112-5.

[9] SALAŠ, O., et al. (2003). Nitride nucleation and growt during plasma and post-discharge nitriding. In: Surface\&Coatings Technology, 163-164, p. 339-346, ISSN 0257-8972.

[10] POKORNÝ, Z., HRUBÝ, V., KUSMIČ D. (2010). Plasma nitridation of Bores in Barrels of small-bore Rifles. Surface treatement. In: Hutnické listy No 2/2010, p. 46 - 50, ISSN 0018-8069.

[11] POKORNÝ, Z., HRUBÝ, V. (2010). Plasma Nitriding of deep narrow Cavities. In: Materials Structure \& Micromechanics of Fracture, Brno, p. 156, ISBN 978-80-214-4112-5.

[12] BASU, A., DUTTA MAJUMDAR, J., et al. (2008). Corrosion resistance improvement of high carbon low alloy steel by plasma nitriding. In: Materials Letters, Vol. 62, p. 3117-3120, ISSN: 0167-577X. 
[13] DONG-CHERNG WEN. (2009). Microstructure and corrosion resistance of the layer formed on the surface of precipitation hardenable plastic steel by plasma-nitriding. In: Applied Surface Science, Vol. 256, p. 797-804, ISSN: 0169-4332.

[14] MAHBOUBI, F., FATTAH, M. (2005). Duplex treatment of plasma nitriding and plasma oxidation of plain carbon steel, In: Vacuum, Vol. 79, No. 1-2, p. 1-6, ISSN 0042-207X.

\section{Paper number: M201512}

Copyright (C) 2015. Published by Manufacturing Technology. All rights reserved. 